Uol. 1, No 1, Seri C, Februari 2019, Hal 277-289
ISSN : 2656-3649 (Online)

http://jea.ppj.unp.ac.id/index.php/jea/issue/view/3

\title{
PENGARUH KARAKTERISTIK PERUSAHAAN TERHADAP PENGUNGKAPAN SUSTAINABILITY REPORTING
}

\author{
${ }^{1)}$ Ihsan Syakirli, ${ }^{2)}$ Charoline Cheisviyanny, ${ }^{3)}$ Halmawati \\ 1) Alumni Jurusan Akuntansi Fakultas Ekonomi Universitas Negeri Padang \\ ${ }^{2,3)}$ Jurusan Akuntansi Fakultas Ekonomi Universitas Negeri Padang \\ *Korespondensi: ihsansyakirli@gmail.com
}

\begin{abstract}
This research aims to give empirical evidences about company's characteristics effects on sustainability reporting disclosure. Information in company's sustainability report disclosure was collected by using GRI indicators. This research is an associative causal. All of company that listed on BEI for 4 years start from 2013 through 2016 used as population in this research while sample was defined bu purposive sampling method and 11 companies as sample. Type of data that we used was secondary data (panel data) from www.idx.com and company's website. Data collection method used documentation method and multiple regression analysist method. The result are profitability, company's size and industrial type have no effect on company's sustainability reporting disclosure. The result of this study contribute directly to the knowledge of corporations providing voluntary disclosure information in form of quality sustainability reports and the importance of the development of globally accepted sustainability reporting standards.
\end{abstract}

Keywords: Company's size; Industrial Type; Profitability; Sustainability Reporting

How to cite (APA $6^{\text {th }}$ style)

Syakirli, Ihsan. (2019). Pengaruh Karakteristik Perusahaan Terhadap Pengungkapan Sustainnability Reporting. Jurnal Eksplorasi Akuntansi, 1(1) Seri C, 277-289.

\section{PENDAHULUAN}

Saat ini banyak perusahaan di Indonesia yang mulai berkembang dan kebanyakan perusahaan masih berfokus pada mencari laba atau keuntungan. Perusahaan menganggap sumbangannya kepda masyarakat hanya berasal dari penyediaan lapangan pekerjaan, pemenuhan kebutuhan melalui produknya dan pembayaran pajak kepada negara sudahlah cukup (Anke, 2009). Anggapan tersebut bukanlah suatu hal yang cukup jika suatu perusahaan ingin membentuk nilai jangka panjang karena sebenarnya masyarakat kemudian tidak hanya menuntut pemenuhan kebutuhan mereka melalui penyediaan produk. Pandangan ini mulai muncul seiring dengan timbulnya berbagai isu mengenai kerusakan lingkungan, masalah sosial dan timbulnya kesadaran masyarakat Indonesia akan pentingnya kinerja lingkungan dan kinerja perusahaan. Kesadaran ini 
yang mendorong masyarakat menginginkan adanya pengungkapan informasi oleh perusahaan yang tidak hanya sebatas satu aspek kinerja saja, melainkan keseluruhan indikator, kinerja keberlanjutan (sustainability performance) yaitu kinerja ekonomi, sosial dan lingkungan (Ken dan Adam, 2012). Tidak hanya memberikan kontribusi terhadap pertumbuhan ekonomi saja, perusahaan juga dituntut dapat membantu dalam memecahkan permasalahan terkait risiko dan ancaman keberlanjutan dalam lingkup hubungan sosial, lingkungan dan perekonomian (GRI 2006).

Publikasi sustainability report dinilai bisa menjadi salah satu cara untuk meningkatkan kredibilitas laporan yaitu dengan membuat laporan tentang kinerja di bidang tanggung jawab sosial yang dapat diperbandingkan tahun demi tahun dan dengan laporan yang dihasilkan oleh organisasi sepadan, serta kesesuaian pelaporan dengan petunjuk pelaporan yang dihaslikan oleh organisasi eksternal (ISO 26000 Klausul 7.6.2). menurut UNCG (2010) dalam Przychodzen (2013) dijelaskan bahwa konsep keberlanjutan awalnya diluncurkan sebagai ide lingkungan yang difokuskan pada konversasi sumber daya. Saat ini telah menjadi tonggak untuk seluruh komunitas bisnis.

Fenomena mengenai kerusakan lingkunagn telah banyak terjadi diantaranya kerusakan yang disebabkan oleh PT Freeport dan PT Indo Sawit Perkasa (ISP). Pada tanggal 1 Mei 2017, BPK menyatakan Freeport menyebabkan kerusakan lingkungan di Papua karena membuang limbah hasil penambangan ke hutan, sungai, muara dan laut. Total potensi kerugian lingkungan yang timbul mancapai RP 185 triliun. "Nilai itu adalah hasil kalkulasi oleh Institut Pertanian Bogor yang ditelaah BPK dalam konteks keuangan negara," kata Ketua BPK Moermahadi Soerja Djanegara kepada Tempo (bisnis.tempo.co).

Profitabilitas menunjukkan seberapa besar kinerja keuangan perusahaan dalam menghasilkan atau memperoleh keuntungan menurut Sembiring (2005) dalam Maria Wijaya (2012). Pengelolaan manajemen perusahaan yang baik ditandai dengan adanya peningkatan profitabilitas. Hal ini menunjukkan bahwa perusahaan mampu memenuhi harapan stakeholder-nya terutama investor dan kreditor sehingga akan timbul kepercayaan yang tinggi untuk lebih banyak mengungkapkan informasi kepada stakeholder.

Ukuran perusahaan merupakan skala yang menentukan besar atau kecilnya perusahaan. Tolak ukur yang menunjukkan besar kecilnya perusahaan antara lain total penjualan, rata-rata tingkat penjualan dan total aset. Pada dasarnya ukuran perusahaan hanya terbagi dalam tiga kategori yaitu perusahaan besar, perusahaan menengah dan perusahaan kecil. Ukuran perusahaan ini didasarkan pada total aset perusahaan (Ati, dkk, 2013).

Tipe industri mendeskripsikan perusahaan berdasarkan lingkup operasi, risiko perusahaan serta kemampuan dalam menghadapi tantangan bisnis (Anindita, 2014). Tipe industri adalah karakteristik yang dimiliki oleh perusahaan yang berkaitan dengan bidang usaha, risiko usaha, karyawan yang dimiliki dan lingkungan perusahaan. Tipe industri dapat dibedakan menjadi perusahaan high profile dan low profile.

Rumusan masalah dari penelitian ini berdasarkan latar belakang di atas yaitu (1) sejauhmana pengaruh profitabilitas terhadap pengungkapan sustainability reporting pada perusahaan yang terdaftar di BEI selama periode 2013-2016, (2) sejauhmana pengaruh ukuran perusahaan terhadap pengungkapan sustainability reporting pada perusahaan yang terdaftar di BEI selama periode 2013-2016, dan (3) Sejauhmana pengaruh tipe industri terhadap pengungkapan sustainability reporting pada perusahaan yang terdaftar di BEI selama periode 2013-2016? 


\section{REVIU LITERATUR DAN HIPOTESIS \\ Teori Legitimasi}

Teori legitimasi merupakan sebuah teori yang memfokuskan pada interaksi antara perusahaan dengan para stakeholders. Perusahaan memerlukan legitimasi atau pengakuan dari investor, kreditor, konsumen, pemerintah maupun masyarakat agar mampu memperthankan kelangsungan hidupnya. Hidayati dan Murni (2009) dalam Pradipta (2015) menyatakan bahwa bagi perusahaan legitimasi dari masyarakat dapat diperoleh jika perusahaan melakukan tanggung jawab sosial. Kesadaran perusahaan bahwa kelangsungan hidup perusahaan sangat tergantung pada hubungan perusahaan dengan masyarakat dan lingkungan, maka sesuai dengan teori legitimasi perusahaan dituntut untuk mampu melakukan aktivitasnya sesuai dengan teori legitimasi perusahaan dituntut untuk mampu melakukan aktivitasnya sesuai dengan nilai-nilai justice dan batasan-batasan norma yang berlaku di masyarakat.

\section{Teori Stakeholders}

Teori stakeholders menunjukkan bahwa perusahaan tidak hanya bertanggung jawab pada kesejahteraan perusahaan saja, melainkan harus memiliki tanggung jawab sosial dengan mempertimbangkan kepentingan semua pihak yang terkena dampak dari tindakan atau kebijakan strategi perusahaan. Kesuksesan suatu perusahaan sangat tergantung pada kemampuannya dalam menyeimbangkan beragam kepentingan para stakeholders atau pemangku kepentingan, Lako (2011) dalam Pradipta (2015).

Dengan adanya teori stakeholders ini kita dapat memberikan landasan bahwa suatu perusahaan harus mampu memberikan manfaat bagi stakeholdernya karena tanggung jawab sosial perusahaan tidak hanya terhadap pemiliknya atau pemegang saham saja tetapi juga terhadap para stakeholders yang terkait dan atau terkena dampak dari keberadaan perusahaan. Manfaat tersebut dapat diberikan dengan cara menerapkan program sustainability reporting. Perusahaan yang menjalankan sustainability reporting akan memperhatikan dampak aktivitas yang dilakukan terhadap kondisi sosial dan lingkungan dan berupaya agar memberikan dampak positif.

\section{Triple-P Bottom Line}

Menurut Elkington (1998), dalam Oktafianti (2015), jika suatu perusahaan ingin mempertahankan kelangsungangan hidupnya, maka perusahaan tersebut harus memperhatikan 3P. Selain mengejar keuntungan (profit), perusahaan juga harus memperhatikan dan terlibat pada pemenuhan kesejahteraan masyarakat (people), dan turut berkontribusi aktif dalam menjaga kelestarian lingkungan lingkungan (planet). Perspektif Triple-P Bottom Line (TBL) berfokus pada perhatian perusahaan terkait biaya sosial dan lingkungan dan manfaat dari tindakan mereka, tidak hanya pada ekonomi (Elkington, 2004 dalam Gallo, 2011). Advokat dari pendekatan TBL umumnya tidak mendukung gagasan bahwa kesejahteraan sosial dan kebugaran lingkungan dapat diukur dengan angka semata (Pava, 2007 dalam Gallo, 2011). Perspektif TBL paling baik dipahami sebagai kerangka kerja yang bertujuan membantu perusahaan mencapai penciptaan nilai ekonomi juga meningkatkan kesejahteraan sosial dan mempertahankan lingkungan.

\section{Profitabilitas}

Profitabilitas merupakan kemampuan perusahaan untuk menghasilkan laba yang merupakan hasil bersih dari kebijakan-kebijakan manajemen, baik dalam mengelola likuiditas, aset ataupun 
utang perusahaan. Semakin tinggi tingkat profitabilitas yang diperoleh akan mencerminkan kinerja keuangan yang baik. Selain itu, hal ini juga menunjukkan tingginya tingkat efisiensi perusahaan dalam memanfaatkan fasilitas perusahaan. Tingkat profitabilitas yang tinggi mengimplikasikan perusahaan pada kepercayaan yang tinggi dalam menginformasikan kemampuan perusahaan untuk memenuhi keinginan stakeholders terutama investor dan kreditor (Suryono, 2011).

\section{Ukuran Perusahaan}

Ukuran suatu perusahaan dapat mempengaruhi luas pengungkapan informasi perusahaan. Secara umum perusahaan besar akan mengungkapkan informasi lebih banyak daripada perusahaan kecil. Perusahaan besar umumnya memiliki aset yang besar, penjualan besar, karyawan yang banyak, sistem informasi yang canggih, jenis produk yang banyak dan struktur kepemilikan yang lengkap sehingga membutuhkan tingkat pengungkapan secara luas. Perusahaan besar mempunyai biaya informasi yang rendah, kompleksitas dan dasar kepemilikan yang lebih luas dibandingkan perusahaan kecil sehingga perusahaan besar cenderung mengungkapan informasi yang lebih luas (Suryono, 2011). Ukuran perusahaan dalam penelitian ini dapat dilihat dari total aset.

\section{Tipe Industri}

Tipe industri mendeskripsikan perusahaan berdasarkan lingkup operasi, risiko perusahaan serta kemampuan dalam menghadapi tantangan bisnis. Tipe industri dibagi menjadi dua bagian yaitu industri high profile dan low profile. Perusahaan-perusahaan high profile pada umumnya merupakan perusahaan yang memperoleh perhatian dari masyarakat karena aktivitas operasinya memiliki potensi untuk bersinggungan dengan kepentingan luas (Anindita, 2014). Pada penelitian ini perusahaan yang terklasifikasi dalam kelompok industri high profile antara lain perusahaan perminyakan dan pertambangan lain, kimia, hutan, kertas, otomotif, penerbangan, agribisnis, tembakau dan rokok, produk makanan dan minuman, media dan komunikasi, energi (listik), engginering, kesehatan serta transportasi dan pariwisata.

Perusahaan low profile adalah perusahaan yang tidak terlalu memperoleh perhatian luas dari masyarakat manakala operasi yang mereka lakukan mengalami kegagalan atau kesalahan pada aspek tertentu dalam proses atau hasil produksinya (Anindita, 2014). Adapun perusahaan yang termasuk dalam kelompok industri low profile antara lain perusahaan bangunan, keuangan dan perbankan, supplier peralatan medis, property, retailer, tekstil, produk personal dan produk rumah tangga (Rachman, 2011). Tipe industri diukur menggunakan variabel dummy, yaitu nilai 1 untuk perusahaan high profile dan nilai 0 untuk perusahaan low profile.

\section{Hubungan antara Profitabilitas dengan Pengungkapan Sustainability Reporting}

Profitabilitas merupakan faktor yang memberikan kebebasan dan fleksibilitas kepada manajemen untuk melakukan dan mengungkapkan informasi sukarela secara luas. Perusahaan yang memiliki kemampuan kinerja keuangan yang baik, akan memiliki kepercayaan yang tinggi untuk member informasi kepada stakeholder-nya, karena perusahaan mampu menunjukkan kepada mereka bahwa perusahaan dapat memenuhi harapan mereka terutama investor dan kreitor. Dengan demikian, semakin tinggi tingkat profitabilitaas perusahaan maka akan semakin besar pula pengungkapan informasi sosial (Munif, 2010 dalam Fahirza, 2014).

$\mathbf{H}_{1}$ : Profitabilitas berpengaruh positif terhadap pengungkapan sustainability reporting. 
Hubungan antara Ukuran Perusahaan dengan Pengungkapan Sustainability Reporting

Ukuran perusahaan menggambarkan besar atau kecilnya total aset yang dimiliki oleh perusahaan. Total aset adalah keseluruhan sumber daya yang dimiliki oleh entitas bisnis atau usaha. Sumber daya dapat berbentuk fisik ataupun hak yang mempunyai nilai ekonomis (Warren, 2006). Semakin besar aset perusahaan maka akan semakin banyak kegiatan operasi perusahaan. Aktivitas operasi perusahaan sangat berkaitan dengan kondisi sosial dan lingkungan sekitar perusahaan, hal inilah membuat banyak perusahaan besar cenderung mengungkapkan informasi yang lebih banyak dibandingkan perusahaan kecil.

$\mathbf{H}_{2}$ : Ukuran perusahaan berpengaruh positif terhadap pengungkapan sustainability reporting

\section{Hubungan antara Tipe Industri dengan Pengungkapan Sustainability Reporting}

Tipe industri mendeskripsikan perusahaan berdasarkan lingkup operasi, risiko perusahaan serta kemampuan dalam menghdapai tantangan bisnis. Perusahaan-perusahaan high profile, pada umumnya merupakan perusahaan yang memperoleh perhatian dari masyarakat karena aktivitas operasinya memiliki potensi untuk bersinggungan dengan kepentingan luas (Anindita, 2014).

Oleh karena itu, pengungkapan tanggung jawab sosial perusahaan diperlukan sebagai media oleh perusahaan untuk mempertanggungjawabkan pelaporan kegiatan sosial yang telah diberikan kepada masyarakat. Sehingga hal ini menunjukkan bahwa perusahaan high profile melakukan pengungkapan sukarela sustaibnability reporting yang lebih banyak dibandingkan perusahaan low profile.

$\mathbf{H}_{3}$ : Perusahaan high profile lebiih banyak melakukan pengungkapan sustainability reporting dibandingkan perusahaan low profile.

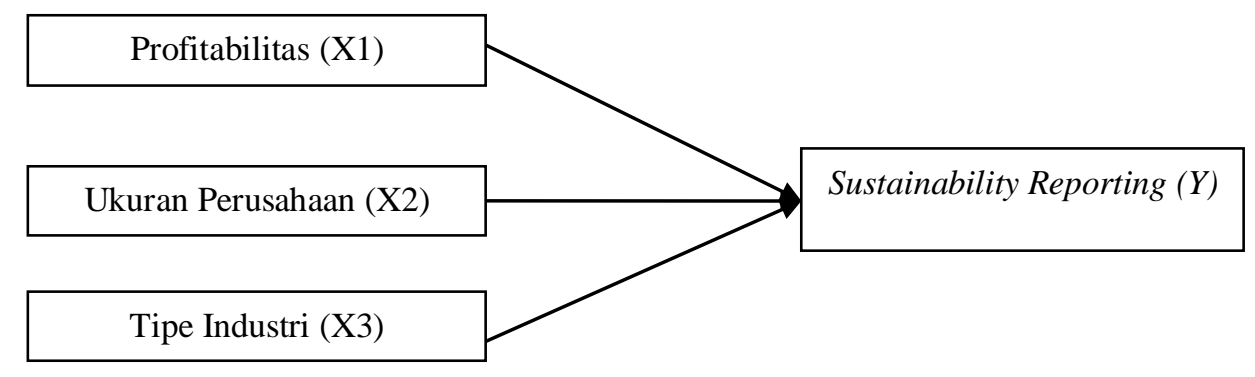

Gambar 1. Kerangka Konseptual

\section{METODE PENELITIAN}

Penelitian ini tergolong penelitian kausatif yaitu penelitian untuk menganalisis pengaruh beberapa variabel terhadap variabel lainnya. Penelitian ini menjelaskan pengaruh profitabilitas (X1), ukuran perusahaan (X2) dan tipe industri (X3) sebagai variabel independen terhadap pengungkapan sustainability reporting (Y) pada perusahaan yang terdaftar di BEI dan menerbitkan sustainability reporting pada tahun 2013-2016. Populasi peneliti adalah pada seluruh perusahaan yang terdaftar di Bursa Efek Indonesia periode 2013-2016 dengan menggunakan teknik purposive sampling.

Teknik pengumpulan data menggunakan teknik observasi dokumentasi dengan melihat laporan tahunan perusahaan sampel yang diterbitkan oleh perusahaan sampel dari tahun 2013 
sampai 2016. Data diperoleh dari situs resmi Bursa Efek Indonesia (www.idx.co.id), web-web resmi perusahaan sampel, dam web-web terkait lainnya serta dengan cara mempelajari literatur yang berkaitan dengan permasalahan penelitian baik media cetak maupun elektronik. Data dianalisis dengan melakukan uji asumsi klasik dan uji regresi berganda dengan bantuan program SPSS for windows versi 16. Model penelitian ini sebagai berikut:

Dimana:

$$
\mathrm{Y}=\mathrm{a}+\mathrm{b}_{1} \mathrm{x}_{1}+\mathrm{b}_{2} \mathrm{x}_{2}+\mathrm{b}_{3} \mathrm{x}_{3}+\mathrm{e}
$$

$\mathrm{Y}=$ Sustainability reporting

$\mathrm{A}=$ Konstanta

b1b2b3 = Koefisien regresi dari setiap variabel independen

$\mathrm{X}_{1}=$ Profitabilitas

$\mathrm{X}_{2}=$ Ukuran perusahaan

$\mathrm{X}_{3}=$ Tipe industri

\section{HASIL DAN PEMBAHASAN}

\section{Hasil Penelitian}

Populasi yang digunakan dalam penelitian ini adalah seluruh perusahaan yang terdaftar di Bursa Efek Indonesia selama periode 2013 sampai 2016. Dengan menggunakan metode purposive sampling, maka diperoleh 11 perusahaan yang memenuhi criteria untuk dijadikan sampel.

Penelitian ini menggunakan statistik deskriptif, untuk memberikan gambaran tentang masing-masing variabel yang akan diteliti.

Tabel 1

Statistik Deskriptif

\begin{tabular}{|l|r|r|r|r|r|}
\hline & $\mathrm{N}$ & Minimum & Maximum & \multicolumn{1}{c|}{ Mean } & Std. Deviation \\
\hline SR & 44 & .30 & .91 & .4836 & .14759 \\
Profitabilitas & 44 & -.05 & .17 & .0627 & .05732 \\
UkuranPerusahaan & 44 & 13.07 & 15.00 & 13.8868 & .59102 \\
TipeIndustri & 44 & .00 & 1.00 & .5455 & .50369 \\
Valid N (listwise) & 44 & & & & \\
\hline
\end{tabular}

Sumber: Olahan Data Spss16

Berdasarkan tabel deskriptif diatas dapat dilihat statistik deskriptif dari masing-masing variabel. Pada variabel sustainability reporting $(\mathrm{Y})$ dengan jumlah data $(\mathrm{N})$ adalah 44 , memiliki nilai minimum 0.30, nilai maksimum 0.91, nilai rat-rata 0.4836 dengan standar deviasi 0.14759 . Variabel profitabilitas (X1) memiliki jumlah data (N) 44, nilai minimum -0.05, nilai maksimum 0.17 , nilai rata-rata 0.0627 dengan standar deviasi 0.05732 . Variabel ukuran perusahaan (X2) jumlah data $(\mathrm{N}) 44$ memiliki nilai maksimum 15.00, minimum 13.07, nilai rata-rata 13.8868 dengan standar deviasi 0.59102. Dan untuk variabel tipe industri (X3) dengan memiliki standar deviasi 0.50369 dengan jumlah data $(\mathrm{N}) 44$, nilai minimum 0.00 , nilai maksimum 1.00 dan nilai rata-rata 0.5455 . 
Tabel 2

Uji Normalitas

\begin{tabular}{|c|c|c|}
\hline & & $\begin{array}{l}\text { Unstandardized } \\
\text { Residual }\end{array}$ \\
\hline $\mathrm{N}$ & & 44 \\
\hline \multirow[t]{2}{*}{ Normal Parameters ${ }^{\mathrm{a}}$} & Mean & .0000000 \\
\hline & Std. Deviation & .12795022 \\
\hline \multirow[t]{3}{*}{ Most Extreme Differences } & Absolute & .205 \\
\hline & Positive & .205 \\
\hline & Negative & -.080 \\
\hline Kolmogorov-Smirnov Z & & 1.357 \\
\hline Asymp. Sig. (2-tailed) & & .050 \\
\hline
\end{tabular}

a. Test distribution is Normal.

Pada penelitian ini uji normalitas dilakukan dengan metode Kolmogorv-Smirnov dengan melihat tingkat signifikansi uji Kolmogorv-Smirnov $>0.05$ berarti residual dinyatakan terdistribusi normal, dan begitu juga sebaliknya.

Tabel 3

Uji Multikolinearitas

\begin{tabular}{|c|c|c|c|c|c|c|c|c|}
\hline \multirow{2}{*}{\multicolumn{2}{|c|}{ Model }} & \multicolumn{2}{|c|}{ Unstandardized Coefficients } & \multirow{2}{*}{ 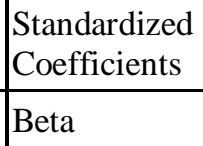 } & \multirow[b]{2}{*}{$\mathrm{T}$} & \multirow[b]{2}{*}{ Sig. } & \multicolumn{2}{|c|}{$\begin{array}{l}\text { Collinearity } \\
\text { Statistics }\end{array}$} \\
\hline & & B & Std. Error & & & & Tolerance & VIF \\
\hline \multirow[t]{5}{*}{1} & (Constant) & 1.680 & .537 & & 3.131 & .003 & & \\
\hline & Profitabilita & -.317 & .391 & -.123 & -.810 & .423 & .814 & 1.229 \\
\hline & & & & & & & & \\
\hline & $\begin{array}{l}\text { Ukuranperu } \\
\text { sahaan }\end{array}$ & -.088 & .038 & -.352 & -2.319 & .026 & .817 & 1.223 \\
\hline & $\begin{array}{l}\text { Tipe } \\
\text { Industri }\end{array}$ & .078 & .049 & .267 & 1.608 & .116 & .682 & 1.466 \\
\hline
\end{tabular}

a. Dependent Variable: SR

Berdasarkan tabel 3 diatas dapat dilihat hasil perhitungan nilai tolerance dan VIF. Nilai tolerance untuk variabel profitabilitas (X1) sebesar 0.814 dengan nilai VIF sebesar 1.229. Untuk variabel ukuran perusahaan (X2) mempunyai nilai tolerance sebesar 0.817 dengan nilai VIF sebesar 1.223. Untuk variabel tipe industri (X3) nilai tolerance sebesar 0.682 dengan nilai VIF sebesar 1.466. Masing-masing variabel independen tersebut memiliki angka tolerance diatas 0.1 dan VIF $<$ 10, jadi dapat disimpulkan bahwa tidak terdapat gejala multikolinearitas antar variabel independen. 
Tabel 5

Uji Autokorelasi

\begin{tabular}{|l|l|l|l|l|l|}
\hline Model & $\mathrm{R}$ & $\mathrm{R}$ Square & $\begin{array}{l}\text { Adjusted } \\
\text { Square }\end{array}$ & $\begin{array}{l}\text { Rtd. Error of the } \\
\text { Estimate }\end{array}$ & Durbin-Watson \\
\hline 1 & $.498^{\mathrm{a}}$ & .248 & .192 & .133 & 1.972 \\
\hline
\end{tabular}

a. Predictors: (Constant), TipeIndustri, UkuranPerusahaan, Profitabilitas

b. Dependent Variable: SR

Tabel 4

Uji Heteroskedastisitas

\begin{tabular}{|c|c|c|c|c|c|c|}
\hline \multirow{2}{*}{\multicolumn{2}{|c|}{ Model }} & \multicolumn{2}{|c|}{ Unstandardized Coefficients } & \multirow{2}{*}{\begin{tabular}{|l|}
$\begin{array}{l}\text { Standardized } \\
\text { Coefficients }\end{array}$ \\
Beta \\
\end{tabular}} & \multirow[b]{2}{*}{$\mathrm{T}$} & \multirow[b]{2}{*}{ Sig. } \\
\hline & & B & Std. Error & & & \\
\hline \multirow[t]{4}{*}{1} & (Constant) & .343 & .346 & & .993 & .327 \\
\hline & Profitabilitas & -.120 & .252 & -.081 & -.476 & .636 \\
\hline & Ukuran Perusahaan & -.019 & .024 & -.129 & -.767 & .448 \\
\hline & Tipe Industri & .033 & .031 & .198 & 1.069 & .291 \\
\hline
\end{tabular}

a. Dependent Variable: RES2

Berdasarkan tabel 4 diatas dapat dilihat bahwa hasil perhitungan masing-masing variabel menunjukkan level sig $>\alpha 0.05$ yaitu 0.636 untuk profitabilitas, ukuran perusahaan sebesar 0.448, serta tipe industry sebesar 0.291. Jadi dapat disimpulkan penelitian ini bebas dari gejala heterokedastisitas dan layak untuk diteliti.

Berdasarkan statistik Durbin Watson diketahui bahwa dengan $\mathrm{n}$ (variabel bebas) $=3, \mathrm{k}$ (jumlah observasi $)=44$, didapatkan nilai $\mathrm{DL}=1.3749$ dan $\mathrm{DU}=1.6647$. Berdasarkan tabel 5 terlihat bahwa nilai $\mathrm{DW}=1.972$, nilai $\mathrm{DU}=1.6647$ dan nilai $4-\mathrm{Du}=4-1.6647=2.3353$ maka DU $<$ DW $<4-$ DU, $1.6647<1.972<2.3353$ maka dapat disimpulkan jika data penelitian tidak terdapat autokorelasi.

Tabel 6

Uji F

\begin{tabular}{|ll|r|r|r|r|r|}
\hline Model & & Sum of Squares & Df & Mean Square & F & Sig. \\
\hline 1 & Regression & .233 & 3 & .078 & 4.407 & $.0099^{\mathrm{a}}$ \\
Residual & .704 & 40 & .018 & & \\
& Total & .937 & 43 & & & \\
\hline
\end{tabular}

a. Predictors: (Constant), TIPE INDUSTRI, SIZE, PROFITABILITAS

b. Dependent Variable: SR 


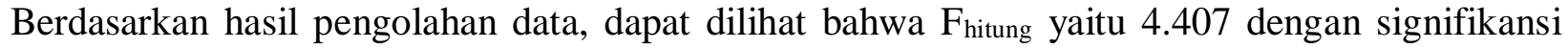
yaitu $0.009<0.05$. Karena nilai signifikansi kecil dari 0.05 maka model regresi yang digunakan sudah fix, sehingga dapat digunakan untuk memprediksi variabel-variabel penelitian. Berarti profitabilitas, ukuran perusahaan dan tipe industry berpengaruh signifikan secara bersama-sama terhadap sustainability reporting.

Tabel 7

Adjusted R Square

\begin{tabular}{|l|r|r|r|r|}
\hline Model & \multicolumn{1}{|c|}{$\mathrm{R}$} & R Square & \multicolumn{1}{c|}{$\begin{array}{c}\text { Adjusted R } \\
\text { Square }\end{array}$} & $\begin{array}{c}\text { Std. Error of the } \\
\text { Estimate }\end{array}$ \\
\hline 1 & $.498^{\mathrm{a}}$ & .248 & .192 & .133 \\
\hline
\end{tabular}

a. Predictors: (Constant), TIPE INDUSTRI, SIZE, PROFITABILITAS

Hasil pengujian dari tabel diatas menunjukkan nilai Adjusted $R$ Square sebesar 0.192. Hal ini berarti $19.2 \%$ nilai sustainability reporting di pengaruhi oleh ke-tiga variabel independen yaitu profitabilitas, ukuran perusahaan dan tipe industry. Sedangkan $80.8 \%$ dipengaruhi oleh variabel lain yang tidak diteliti.

Tabel 8

Uji Hipotesis

\begin{tabular}{|c|c|c|c|c|c|c|}
\hline \multirow{2}{*}{\multicolumn{2}{|c|}{ Model }} & \multicolumn{2}{|c|}{ Unstandardized Coefficients } & \multirow{2}{*}{$\begin{array}{c}\text { Standardized } \\
\text { Coefficients }\end{array}$} & \multirow[b]{2}{*}{$\mathrm{t}$} & \multirow[b]{2}{*}{ Sig. } \\
\hline & & B & Std. Error & & & \\
\hline \multirow[t]{4}{*}{1} & (Constant) & 1.680 & .537 & & 3.131 & .003 \\
\hline & PROFITABILITAS & -.317 & .391 & -.123 & -.810 & .423 \\
\hline & SIZE & -.088 & .038 & -.352 & -2.319 & .026 \\
\hline & TIPE INDUSTRI & .078 & .049 & .267 & 1.608 & .116 \\
\hline
\end{tabular}

a. Dependent Variable: SR

Pengujian hipotesis dilakukan dengan membandingkan $t_{\text {hitung }}$ dengan nilai $t_{\text {tabel }}$. Hipotesis diterima jika $t_{\text {hitung }}>t_{\text {tabel }}$ atau nilai sig $<0.05$. Profitabilitas (X1) memiliki $t_{\text {hitung }}<t_{\text {tabel }}$ yaitu $0.810<-1.683$ dengan nilai signifikansi besar dari $\alpha$ yaitu $0.423>\alpha 0.05$ dan nilai koefisien $\beta$ sebesar -0.123. Hal ini menunjukkan bahwa variabel profitabilitas (X1) tidak berpengaruh terhadap pengungkapan sustainability reporting (Y), sehingga dapat disimpulkan hipotesis 1 ditolak.

Pengujian hipotesis dilakukan dengan membandingkan $t_{\text {hitung }}$ dengan nilai $t_{\text {tabel. }}$. Hipotesis diterima jika $t_{\text {hitung }}>t_{\text {tabel }}$ atau nilai sig $<0.05$. Ukuran perusahaan (X2) memiliki $t_{\text {hitung }}<t_{\text {tabel }}$ yaitu $-2.319<1.683$ dengan nilai signifikansi kecil dari $\alpha$ yaitu $0.026<\alpha 0.05$ dan nilai koefisien $\beta$ sebesar -0.088. Hal ini menunjukkan bahwa variabel ukuran perusahaan (X2) tidak berpengaruh terhadap pengungkapan sustainability reporting $(\mathrm{Y})$, sehingga dapat disimpulkan hipotesis 2 ditolak.

Pengujian hipotesis dilakukan dengan membandingkan $t_{\text {hitung }}$ dengan nilai $t_{\text {tabel. }}$. Hipotesis diterima jika $t_{\text {hitung }}>t_{\text {tabel }}$ atau nilai sig $<0.05$. Tipe industry $(\mathrm{X} 3)$ memiliki $t_{\text {hitung }}<T_{\text {tabel yaitu }}$ $1.608<1.683$ dengan nilai signifikansi besar dari $\alpha$ yaitu $0.116>0.05$ dan nilai koefisien $\beta$ 
sebesar 0.267. Hal ini menunjukkan bahwa pada variabel tipe industri (X3) perusahaan high profile tidak selalu lebih banyak melakukan pengungkapan sustainability reporting (Y) dibandingkan dengan perusahaan low profile sehingga hipotesis 3ditolak.

\section{Pembahasan \\ Pengaruh Profitabilitas Terhadap Sustainability Reporting}

Hasil penelitian menunjukkan bahwa profitabilitas tidak berpengaruh signifikansi terhadap pengungkapan sustainability reporting. Temuan ini sejalan dengan penelitian Adistira (2013), Luthfia (2011), Fahriza (2014), Iswari (2016) dan James (2017) yang menyatakan bahwa profitabilitas tidak berpengaruh terhadap pengungkapan sustainability reporting. Hal ini menunjukkan bahwa perusahaan yang mengungkapkan sustainability reporting masih menggunakan pertimbangan cost-benefit dalam menerbitkan sustainability reporting, karena pengungkapan sustainability reporting akan banyak memakan biaya dan belum dianggap penting oleh perusahaan, hal itu menyebabkan banyak perusahaan yang tidak mengungkapkan sustainability reporting.

Hal ini juga sejalan dengan teori legitimasi yang menyebutkan bahwa ketika paerusahaan memiliki tingkat laba yang tinggi, pihak manajemen menganggap tidak perlu melaporkan hal-hal yang dapat mengganggu informasi tentang kesuksesan keuangan perusahaan. Dan ketika tingkat profitabilitas rendah, manajemen berharap para pengguna laporan akan membaca "good news" kinerja perusahaan, misalnya dalam lingkup sosial sehingga investor akan tetap berinvestasi pada perusahaan tersebut (Adistira, 2013). Hasil penelitian ini tidak sejalan dengan penelitian yang dilakukan oleh Anindita (2014), Hari dan Prastiwi (2011), Azwir dkk (2014), dan Idah (2013) yang menemukan bahwa profitabilitas berpengaruh positif terhadap pengungkapan sustainability reporting.

\section{Pengaruh Ukuran Perusahaan Terhadap Pengungkapan Sustainability Reporting}

Hasil penelitian ini menunjukkan bahwa ukuran perusahaan tidak berpengaruh terhadap pengungkapan sustainability reporting. Temuan ini sejalan dengan penelitian yang dilakukan Rakhman (2017), Azwir (2014) yang menemukan bahwa ukuran perusahaan tidak berpengaruh terhadap pengungkapan sustainability reporting. Hal ini mungkin terjadi dikarenakan pengungkapan tanggung jawab sosial dalam laporan keberlanjutan merupakan masalah kebijakan sosial dan dasarnya adalah voluntary.

Keputusan untuk melakukan suatu tanggung jawab sosial dan untuk mengungkapkannya merupakan kebijakan manajemen. Sehingga informasi yang diungkapkan oleh perusahaan tingkat pengungkapannya berbeda-beda sesuai dengan kebijakan manajemen masing-masing perusahaan. Kebijakan manajemen diambil dengan melihat cost and benefit dari melakukan pengungkapan tersebut bagi perusahaan.

\section{Pengaruh Tipe Industri Terhadap Pengungkapan Sustainability Reporting}

Hasil ini menunjukkan bahwa tipe industry tidak berpengaruh terhadap pengungkapan sustainability reporting dikarenakan tipe industri disini hanya menunjukkan perbedaan kelompok perusahaan berkaitan dengan karakteristik yang dimiliki oleh perusahaan terkait dengan bidang usaha, risiko usaha, karyawan yang dimiliki dan lingkungan perusahaan sehingga perbedaan tipe industri tidak menunjukkan pengaruh yang signifikan terhadap pengungkapan 
sustainability reporting. Hasil penelitian ini sejalan dengan penelitian yang dilakukan oleh Puspowardhani (2013), Ismurniati (2010) dan Lestari dan Chariri (2007).

Undang-undang Perseroan Terbatas No.40 Tahun 2007 Pasal 74 Ayat 1, yang mengatur tentang kesadaran akan perlunya menjaga lingkungan, menyatakan bahwa "perseroan yang menjalankan kegiatan usahanya di bidang dan/atau berkaitan dengan sumber daya alam wajib melaksanakan tanggung jawab sosial dan lingkungan". Hal ini mengindikasikan bahwa baik perusahaan tersebut high profile maupun low profile, mereka akan tetap membuat sustainability reporting yang didasarkan atas peraturan diatas dan juga kesadaran manajemen, walaupun baru sebagian perusahaan saja yang menerapkan. Selain itu, setiap perusahaan pasti ingin member image yang baik dikalangan masyarakat, salah satunya dengan mempublikasikan sustainability reporting (Lestari dan Chariri, 2007). Hasil penelitian ini tidak sejalan dengan penelitian yang dilakukan oleh Anindita (2014), Ahmad (2014), dan Adistira (2013).

\section{KESIMPULAN, KETERBATASAN DAN SARAN \\ Kesimpulan}

Berdasarkan hasil penelitian dan pembahsan yang telah disajikan pada bab-bab sebelumnya, maka dapat diambil kesimpulan bahwa profitabilitas, ukuran perusahaan, dantipe industri tidak berpengaruh terhadap pengungkapan sustainability reporting pada perusahaan yang terdaftar di BEI selama periode 2013-2016.

\section{Keterbatasan}

Meskipun peneliti telah berusaha merancang dan mengembangkan penelitian sedemikian rupa, namun masih terdapat beberapa keterbatasan dalam penelitian ini, diantaranya yaitu: (1) Rendahnya nilai Adjusted $R$ square sehingga pengaruh variabel penelitian rendah yaitu sebesar $19,2 \%$. (2) Penelitian ini hanya dilakukan pda perusahaan yang terdaftar di BEI dan pada GRI G4 dengan periode pengamatan empat tahun padahal data pada NCSR menyebutkan bahwa terdapat perusahaan yang tidak terdaftar di BEI juga menerbitkan sustainability reporting seperti Kaltim Prima Coal dan Pertamina. (3) Masih adanya sejumlah variabel lain yang tidak digunakan dan memiliki kontibusi yang mempengaruhi pengungkapan sustainability reporting.

\section{Saran}

Dari kesimpulan dan keterbatasan yang telah diuraikan diatas, maka dalam kesempatan ini penulis mencoba untuk memberikan saran-saran sebagai berikut: (1) Bagi perusahaan, diharapkan hasil penelitian ini dapat memberikan masukan mengenai faktor-faktor serta manfaat dari sustainability reporting, (2) Bagi peneliti selanjutnya, memperpanjang periode pengamatan seperti penelitian Dilling (2009) selama 5 tahun. Menjadikan semua perusahaan yang menerbitkan sustainability reporting sampel penelitian termasuk perusahaan non-publik seperti Kaltim Prima Coal, Pertamina dan lainnya. (3) Menambahkan variabel lain yang diduga dapat mempengaruhi sustainability reporting perusahaan, seperti: struktur modal, kinerja keuangan, GCG dan lainnya. 


\section{DAFTAR PUSTAKA}

Adistira, S,A. (2012). Pengaruh Karakteristik Perusahaan terhadap Pengungkapan Sustainability Reporting. Jurnal Reviw Akuntansi dan Keuangan. 3(1), 403-414.

Ahmad, F. 2014. Pengaruh Karakteristik Perusahaan dan Profitabilitas Terhadap Pengungkapan Sustainability Reporting. Skripsi. Program Studi Akuntansi Program Sarjana Universitas Negeri Padang.

Anindita, M. (2014). Pengaruh Ukuran Perusahaan, Profitabilitas, dan Tipe Industri terhadap Pengungkapan Sukarela Pelaporan Keberlanjutan. Jurnal Akuntansi dan Keuangan Indonesia.

Anke. (2009). Analisis pelaksanaan SR pada PT Semen Gresik (Persero) Tbk. Jurnal Akuntansi \& Auditing 8(1).

Ati, R.S., Sutrisno dan Eko, G.S. (2013). Pengaruh Kepemilikan Institusional, Komposisi Dewan Komisaris, Kinerja Perusahaan terhadap Luas Pengungkapan Corporate Social Responsibility di dalam Sustainability Report pada Perusahaan Manufaktur yang Terdaftar di BEI. Jurnal Aplikasi Manajemen 11(3).

Azwir, Nasir, Elfi, I. dan Vadela, I.U. (2014). Pengaruh Karakteristik Perusahaan dan Corporate Governance Terhadap Pengungkapan Sustainability Report pada Perusahaan LQ45 yang Terdaftar. Jurnal Ekonomi, 22 (1).

Dilling, Petra, F.A. (2010). Sustainability Reporting In A Global Context: What Are The Characreristics Of Corporations That Provide High Quality Sustainability Reports -An Empirical Analysis. International Business \& Economics Research Journal,. 9 (1).

Fahriza, R. 2014. Faktor-Faktor yang Mempengaruhi Tingkat Pengungkapan Sustainability Report. Program Studi Akuntansi Program Sarjana Universitas Sebelas Maret.

Gallo, Peter, J, Lisa, J.C. (2011). Firm Size Matters: An Empirical Investigation of Organizational Size and Ownership on Sustainability Related Behavior. Journals Permissions Business \& Society.

GRI dan ISO 26000: Bagaimana Menggunakan Panduan GRI Bersama dengan ISO 26000.2010. Diunduh tanggal 12 Oktober 2017.

Idah. (2013). Corporate Governance dan Karakteristik Perusahaan dalam Pengungkapan Sustainability Report. Accounting Analysis Journal, 314- 322.

Iswari. 2016. Pengaruh Karakteristik Perusahaan dan Corporate Governance (GC) Terhadap Praktik Pengungkapan Sustainability Report (SR). Skripsi. Universitas Muhammadiyah Surakarta.

James. (2017). Pengaruh Karakteristik Perusahaan dan Corporate Governance terhadap Praktik Publikasi Sustainability Report pada Perusahaan Publik di Indonesia. JIAFE (Jurnal Ilmiah Akuntansi Fakultas Ekonomi) 3 (1),1-19.

Ken, A.M. dan Helmy, A. 2012. Faktor-Faktor yang Mempengaruhi Pengungkapan Sustainability Performance. Skripsi. Jurusan Akuntansi Fakultas Ekonomi dan Bisnis Universitas Brawijaya.

Luthfia dan Andri, P. 2012. Pengaruh Kinerja Keuangan, Ukuran Perusahaan, Struktur Modal dan Corporate Governance Terhadap Publikasi Sustainability Report. Universitas Diponegoro.

Maria, W. (2012). Faktor-Faktor Yang Mempengaruhi Pengungkapan Tanggung Jawab Sosial Pada Perusahaan Manufaktur Yang Terdaftar Di Bursa Efek Indonesia. Jurnal Ilmiah Mahasiswa Akuntansi, 1(1). 
Oktafianti, D dan Amalia R. (2015). Pengaruh Kepemilikan Manajerial, Ukuran Perusahaan dan Kinerja Keuangan Terhadap Corporate Environmental Disclosure Sebagai Bentuk Tanggung Jawab Sosial dalam Laporan Tahunan. Simposium Nasional Akuntansi.

Pradipta, D. dan Supriyadi, H. (2015). Pengaruh Corporate Social Responsibility (CSR), Profitabilitas, Leverage, dan Komisaris Independen Terhadap Praktik Penghindaran Pajak. Simposium Nasional Akuntansi.

Rakhman, A. 2017. Pengaruh Karakteristik Perusahaan Terhadap Keputusan Penerapan Assurance Laporan Keberlanjutan.

Rachman, S.M. 2011. Analisis Komparatif Kinerja Lingkungan Antara Perusahaan High Profile dan Low Profile Periode 2011. Universitas Negeri Surabaya.

Suryono, H dan Andri, P. (2011). Pengaruh Karakteristik Perusahaan dan Corporate Governance (CG) Terhadap Praktik Pengungkapan Sustainability Report (SR). Simposium Nasional Akuntansi.

Undang-Undang RI Nomor 40 Tahun 2007 Tentang Perseroan Terbatas.

Waren, et al. (2008). Pengantar Akuntansi. Jakarta: Salemba Empat. 